\title{
Problems of continuity between preschool and elementary school
}

Elviza K. Rakhimova ${ }^{*}$,

Natalya N. Zinina ${ }^{b}$,

Gulnora K. Ibragimova ${ }^{c}$,

Suggested Citation:

New Trends and Issues Proceedings on Humanities and Social Sciences.

Abstract 
1. Introduction 
2. Materials and Methods 


\section{Results}

3.2 Description of the experiment 
Table 1. Results of the development of skills in various educational fields in school year $2013-2014$

\begin{tabular}{l|l|l}
\hline & \multicolumn{2}{|c}{} \\
\cline { 2 - 3 } & & \\
\hline
\end{tabular}

Table 2. Results of the development of integrative qualities in school year 2013 - 2014 
4. Discussion 


\section{Conclusion}

\section{Recommendations}




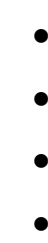

\section{Acknowledgments}

\section{References}

Continuity Between Preschools, Schools and Parents of Future Firstgraders: Methodological Guidebook.

Personal Psychology: Cultural and Historical Understandingof Human Development.

Regulatory Documents of Educational Institutions, 4. Implementation of Continuity in

Education of Children in Preschool and Elementary School.

Child HealthandSchool Readiness: A guide for parents 